Article

\title{
Sustainable Cornelian Cherry Production in Montenegro: Importance of Local Genetic Resources
}

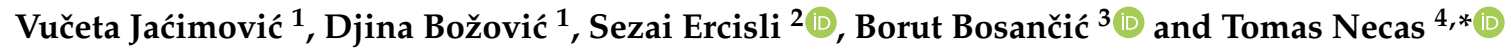 \\ 1 Biotechnical Faculty, University Montenegro, Mihaila Lalića 1, 81000 Podgorica, Montenegro; \\ vucetaj@ucg.ac.me (V.J.); djinab@ucg.ac.me (D.B.) \\ 2 Department of Horticulture, Agricultural Faculty, Ataturk University, 25240 Erzurum, Turkey; \\ sercisli@gmail.com \\ 3 Genetic Resources Institute, Faculty of Agriculture, University of Banja Luka, 78000 Banja Luka, \\ Bosnia \& Herzegovina; borutbosancic@gmail.com \\ 4 Department of Fruit Science, Faculty of Horticulture, Mendel University in Brno, 69144 Lednice, \\ Czech Republic \\ * Correspondence: tomas.necas@mendelu.cz; Tel.: +420-5193-67244
}

Received: 25 September 2020; Accepted: 16 October 2020; Published: 19 October 2020

\begin{abstract}
Cornelian cherries has been grown Balkan peninsula no apparent disease and pest problems for centuries. The most important pomological and technological properties of cornelian cherry genetic resources (eleven local and introduced varieties and selections) in Gornje Polimlje, Montenegro were studied in four-year periods. Fruit weight, stone weight, and mesocarp/stone ratio shows great variation and varied between 1.89 to $6.16 \mathrm{~g}, 0.32$ to $0.64 \mathrm{~g}$ and between 76.66 and $90.59 \%$, respectively. Genotypes significantly differed each other in terms of yield determined as per trunk cross section area (TCSA). For better visualization of the agronomical traits important to the yield, i.e., yield per TCSA and fruit weight data is presented in combination as measured in the years of study. The best promising genotypes are Vladimirskiy, Chisinau yellow, and Krupnoplodni NS, which had consistently higher yield and large fruits for sustainable fruit production. Dry matter, total sugars, reducing sugars, sucrose, total acidity, Ca-pectate, vitamin C, total anthocyanins, total polyphenols, and ash content of cornelian cherry cultivars and selections were found between $19.81-24.46 \%, 10.94-14.47 \%, 10.44-13.09 \%$, 0.24-1.23\%, 1.92-2.51\%, 2.76-4.43\%, 41.09-101.27 mg/100 g, 0-157.06 mg/100 g, 183.91-307.9 mg/100 g, and $0.89-1.16 \%$, respectively. The amount of potassium, which predominates in percentage of minerals in the ash, ranged from 2888 to $3574 \mathrm{mg} / \mathrm{kg}$. The extensiveness of the study leads, therefore, to several clear conclusions and recommendations. Consistently, the best balance of biochemical elements in combination with good yield and fruit size measurements is found in selection Krupnoplodi NS. If consider fruit size and yield efficiency are priority, Vladimirskiy, Chisinau yellow, Kosten 3, and Krupnoplodni NS have clear advantage over the other genotypes. The study highlights the importance of local cornelian cherry selections for sustainable cornelian cherry production in Montenegro.
\end{abstract}

Keywords: Cornus mas; yield; weight; biochemical characteristics

\section{Introduction}

Sustainable fruit production is gained much importance more recently and one of the key principles associated with sustainable fruit production includes use and enhance biological diversity and use of genetic resources [1]. Consumers are also tending to buy fruits that can be classed as sustainable, including local provenance of the fruit and how organic or natural it is $[2,3]$.

Plant genetic resources have been indispensable basic raw material due to their importance for food and agriculture since long time. Traditional and local varieties are very valuable resources, 
well adopted across a wide range of agroclimatic conditions and remarkable resistance against pests and diseases that indicate higher sustainability. They carry many qualities, such as taste, color, and size [3,4]. Local varieties gain importance in the development of new varieties because they show a high degree of genetic diversity within a particular field [1,5].

Cornelian cherry (Cornus mas L.) is spontaneous fruit species, dispersed in East and South regions of Europe and West Asia [6]. It is a slow growing, long living, and very adaptive plant [7]. It grows mostly on the dry, sunny and rocky sides of light deciduous oak forests, together with other shrubs and bushes. Although cornelian cherry has long been known and used as a food and medicine [8], until recently, it belonged to the group of less known fruit species [9].

Lately, there has been an increase in consumer interest in healthy lifestyles, which includes a healthy diet, and producers are returning to this partially forgotten fruit, which is adorned with biologically very valuable fruits for humans with multiple use [10-12]. Ripe cornelian cherry fruits are eaten fresh, frozen, dried or processed into jam, marmalade, slatko (fruit preserve is sugar syrup), composte, fruit juice, syrup, yogurt, wine, liqueur, and brandy, while green fruits are marinated in a saline solution similar to olives [13,14]. Cornelian cherry fruits are rich in essential minerals, vitamins, sugars, acids, tannins, pectins, anthocyanin's, phenolic compounds and other substances, which puts it in line with other more widely used fruit species $[9,11,15,16]$. Almost all the organs of cornelian cherry are used in traditional medicine to treat diarrhoea, cholera, fever, malaria, kidney stones, urinary tract infections, bleeding, and overheating $[17,18]$. The healing properties of cornelian cherry are not ignored by medicine of modern age either, and numerous studies indicate its use in the prevention and treatment of arteriosclerosis, diabetes, high cholesterol, hepatic steatosis, and cancer [19-22]. In addition to the before mentioned, cornelian cherry has been found to have antimicrobial, antiparasitic, anti-inflammatory, and antioxidant effects $[6,23,24]$.

Attractive golden-yellow flowers in early spring, as well as decorative leaves with long duration of leaf color change in autumn, allow the use of cornelian cherry for decorative purposes [25]. Thanks to early flowering, cornelian cherry is a valued honey plant because it provides of nectar and pollen in a period of pollen and nectar deficiency [26].

The area of cornelian cherry distribution in Montenegro reaches sea coast in the South and far North of the country, fruiting at $1300 \mathrm{~m}$ above sea level [27]. Many products made from cornelian cherry fruits harvested from wild trees from nature are traded in Montenegrin markets. Such fruits are produced in the conditions of undisturbed natural relations, without the application of pesticides and mineral fertilizers, meeting the strictest standards for the production of safe food. Fresh fruits of this fruit species or processed products stored without the use of high temperatures and preservatives can be recommended for the safe diet due to their high nutritional value and beneficial effect on health. However, there is a problem with fruit harvesting, as cornelian cherry, as a forest fruit, often grows in inaccessible terrains. The solution to that problem is to establish orchards of this fruit species.

Therefore, the aim of this paper was to examine the most important pomological and technological characteristics of introduced varieties and selections, as well as selections that were isolated from natural populations in Montenegro, in order to recommend them for further expansion and use in cultivation.

\section{Materials and Methods}

\subsection{Plant Material and Field Evaluation}

In the four-year period, four selections of cornelian cherry from Montenegro (Kosten 1, Kosten 2, Kosten 3, and Boro), four selections from Serbia (Apatinski rani, Bačka, Era, and Krupnoplodni NS) and three introduced varieties (Lukyanovskiy, Vladimirskiy, and Chisinau yellow) were studied. The experimental orchard was mainly established in autumn 2008 in the village of Kostenica $\left(43^{\circ}\right.$ $02^{\prime} \mathrm{N}, 19^{\circ} 51^{\prime} \mathrm{E}, 850 \mathrm{~m}$ above sea level), near Bijelo Polje in the northern part of Montenegro. Only the Vladimirskiy variety was subsequently planted in the fall of 2011. Plants were produced by grafting 
on cornelian cherry seedlings and were planted at a distance of $4 \times 4 \mathrm{~m}$. The cultivation form is an improved pyramid. Each variety and selection is represented by five trees. Among the agrotechnical measures in the orchard, fertilization, mulching with green grass under the tree crown, and irrigation were applied. Fertilization was performed with mature bovine manure in the fall of 2011 and 2014 in the amount of $15 \mathrm{~kg}$ per tree. Fruit analysis was performed on mature fruits, in an average sample of 100 fruits per variety and selection (20 fruits per tree), and each tree was observed as one replication. The four-year meteorological data (temperature and precipitation) are given in Table 1.

Table 1. The meteorological data of Kostenica between 2012-2015.

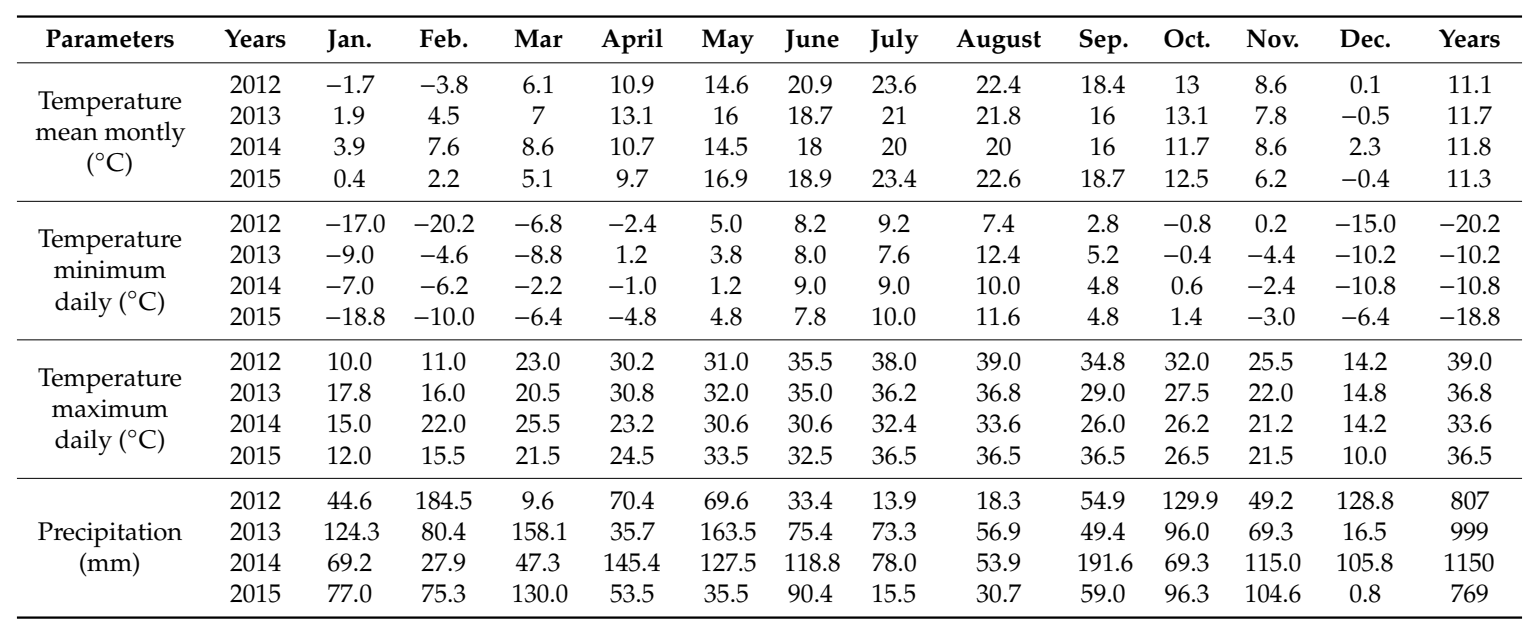

\subsection{Pomological Analysis}

The weight of fruit and stone was determined using analytical scale "Mettler" 1200 . The result is expressed in grams with an accuracy of $0.01 \mathrm{~g}$. Utilization of fruit is presented as a content of mesocarp in total fruit weight expressed as a percentage and as the mesocarp stone ratio. Yield is shown using the yield efficiency which represents the ratio between yield in $\mathrm{kg}$ and trunk cross sectional area (TCSA) in measured in $\mathrm{cm}^{2}$ [28].

\subsection{Biochemical Analysis}

Biochemical analysis of mesocarp included the following tests: Dry Matter (DM), Total Acids (TA), Total Sugar (TS) and Reducing Sugars (RS), sucrose, vitamin C, total anthocyanin, ash, total polyphenols, $\mathrm{Ca}$-pectate, contents of macro and micro elements-sodium $(\mathrm{Na})$, potassium $(\mathrm{K})$, calcium $(\mathrm{Ca})$, magnesium $(\mathrm{Mg})$, phosphorus $(\mathrm{P})$, iron $(\mathrm{Fe})$, zinc $(\mathrm{Zn})$ copper $(\mathrm{Cu})$, and manganese $(\mathrm{Mn})$. Analyses were performed by conventional methodology [29].

\subsection{Statistical Analysis}

Data related to fruit of studied indigenous and leading international genotypes of cornelian cherry was presented with standard descriptive measures and differences were tested by general linear models (GLM). In case of the statistically significant difference detected by GLM, the appropriate post-hoc testing was applied in order to test the individual differences and establish similarity groups. We analyzed both pomological and biochemical characteristics separately and in combination. Combination of all studied characteristics and genotypes was analyzed by Principal Components Analysis (PCA) where grouping patterns were established and presented through appropriate biplots. Statistical significance for observed differences was established at the level of $p<0.05$. Observed statistical differences and groupings were discussed also from perspective of its agronomical significance. Graphical representation and biometrical analysis were conducted with assistance of statistical software packages R 3.1.3 [30] and SPSS 22 [31]. 


\section{Results and Discussion}

\subsection{Pomological Characteristics}

The morphological characteristics of the fruit of the examined varieties and selections are shown in Table 2.

Table 2. Pomological characteristics (mean \pm standard error) of studied Cornelian cherry genotypes with statistical analysis of studied factors indicating statistically significant differences and interactions (F and $p$ values).

\begin{tabular}{|c|c|c|c|c|c|c|c|c|c|c|c|c|c|c|}
\hline \multirow{2}{*}{ Genotype } & \multirow{2}{*}{ Year } & \multicolumn{3}{|c|}{$\begin{array}{l}\text { Fruit Weight } \\
\text { (g) }\end{array}$} & \multicolumn{3}{|c|}{$\begin{array}{l}\text { Pit Weight } \\
\text { (g) }\end{array}$} & \multicolumn{3}{|c|}{$\begin{array}{c}\text { Flesh Content } \\
(\% \text { FW) }\end{array}$} & \multirow{2}{*}{ Color } & \multicolumn{3}{|c|}{$\begin{array}{l}\text { Yield Efficiency } \\
\left(\mathrm{kg} / \mathrm{cm}^{2} \text { TCSA] }\right.\end{array}$} \\
\hline & & $\bar{X}$ & \pm & $\mathrm{S} \overline{\mathbf{x}}$ & $\bar{x}$ & \pm & $\mathrm{S} \overline{\mathrm{x}}$ & $\bar{X}$ & \pm & $\mathrm{S} \overline{\mathbf{x}}$ & & $\bar{X}$ & \pm & $\mathrm{S} \overline{\mathrm{x}}$ \\
\hline \multirow{4}{*}{ Apatinski rani } & 2012 & 2.6 & \pm & 0.15 & 0.49 & \pm & 0.06 & 81.23 & \pm & 1.73 & - & \multirow{4}{*}{0.17} & \multirow{4}{*}{ \pm} & \multirow{4}{*}{0.01} \\
\hline & 2013 & 2.91 & \pm & 0.23 & 0.47 & \pm & 0.06 & 84.26 & \pm & 1.02 & Dark & & & \\
\hline & 2014 & 2.81 & \pm & 0.15 & 0.37 & \pm & 0.02 & 86.72 & \pm & 0.43 & Red & & & \\
\hline & 2015 & 2.70 & \pm & 0.15 & 0.32 & \pm & 0.02 & 88.23 & \pm & 0.3 & - & & & \\
\hline \multirow{4}{*}{ Bačka } & 2012 & 3.27 & \pm & 0.15 & 0.44 & \pm & 0.02 & 86.32 & \pm & 0.78 & - & \multirow{4}{*}{0.19} & \multirow{4}{*}{ \pm} & \multirow{4}{*}{0.02} \\
\hline & 2013 & 3.95 & \pm & 0.18 & 0.52 & \pm & 0.02 & 86.65 & \pm & 0.39 & Dark & & & \\
\hline & 2014 & 3.72 & \pm & 0.09 & 0.48 & \pm & 0.01 & 87.07 & \pm & 0.4 & Red & & & \\
\hline & 2015 & 4.03 & \pm & 0.1 & 0.51 & \pm & 0.02 & 87.35 & \pm & 0.42 & - & & & \\
\hline \multirow{4}{*}{ Boro } & 2012 & 1.89 & \pm & 0.04 & 0.44 & \pm & 0.02 & 76.66 & \pm & 0.87 & - & \multirow{4}{*}{0.10} & \multirow{4}{*}{ \pm} & \\
\hline & 2013 & 2.48 & \pm & 0.14 & 0.52 & \pm & 0.02 & 78.73 & \pm & 0.89 & - & & & \\
\hline & 2014 & 2.06 & \pm & 0.06 & 0.41 & \pm & 0.01 & 80.13 & \pm & 0.4 & Yellow & & & 0.02 \\
\hline & 2015 & 2.17 & \pm & 0.05 & 0.45 & \pm & 0.02 & 79.14 & \pm & 0.71 & - & & & \\
\hline & 2012 & 2.43 & \pm & 0.12 & 0.34 & \pm & 0.02 & 85.54 & \pm & 1.06 & - & & & \\
\hline & 2013 & 3.27 & \pm & 0.14 & 0.39 & \pm & 0.02 & 87.90 & \pm & 0.61 & Dark & & & \\
\hline Era & 2014 & 3.08 & \pm & 0.12 & 0.38 & \pm & 0.02 & 87.71 & \pm & 0.30 & Red & 0.17 & \pm & 0.03 \\
\hline & 2015 & 3.24 & \pm & 0.15 & 0.38 & \pm & 0.01 & 88.01 & \pm & 0.59 & - & & & \\
\hline & 2012 & 3.41 & \pm & 0.12 & 0.46 & \pm & 0.02 & 86.44 & \pm & 0.59 & - & & & \\
\hline Chisinau vellow & 2013 & 5.09 & \pm & 0.17 & 0.62 & \pm & 0.02 & 87.75 & \pm & 0.42 & - & 0 & & \\
\hline Cnisinau yellow & 2014 & 4.74 & \pm & 0.22 & 0.55 & \pm & 0.03 & 88.11 & \pm & 0.74 & Yellow & 0.20 & \pm & 0.03 \\
\hline & 2015 & 4.62 & \pm & 0.19 & 0.53 & \pm & 0.03 & 88.43 & \pm & 0.68 & - & & & \\
\hline & 2012 & 3.15 & \pm & 0.08 & 0.48 & \pm & 0.03 & 84.66 & \pm & 0.76 & - & & & \\
\hline & 2013 & 4.25 & \pm & 0.19 & 0.75 & \pm & 0.02 & 82.29 & \pm & 0.59 & Dark & & & \\
\hline Kosten 1 & 2014 & 3.31 & \pm & 0.1 & 0.51 & \pm & 0.02 & 84.62 & \pm & 0.62 & Red & 0.21 & \pm & 0.03 \\
\hline & 2015 & 3.75 & \pm & 0.17 & 0.54 & \pm & 0.03 & 85.47 & \pm & 0.58 & - & & & \\
\hline & 2012 & 2.82 & \pm & 0.1 & 0.41 & \pm & 0.02 & 85.27 & \pm & 0.74 & - & & & \\
\hline & 2013 & 3.45 & \pm & 0.12 & 0.51 & \pm & 0.02 & 85.16 & \pm & 0.41 & Dark & & & \\
\hline Kosten 2 & 2014 & 3.14 & \pm & 0.15 & 0.47 & \pm & 0.02 & 84.88 & \pm & 0.57 & Red & 0.16 & \pm & 0.02 \\
\hline & 2015 & 2.79 & \pm & 0.14 & 0.41 & \pm & 0.02 & 85.3 & \pm & 0.70 & - & & & \\
\hline & 2012 & 4.09 & \pm & 0.18 & 0.52 & \pm & 0.02 & 87.21 & \pm & 0.34 & - & & & \\
\hline Kosten 3 & 2013 & 4.56 & \pm & 0.22 & 0.59 & \pm & 0.03 & 87.07 & \pm & 0.1 & - & & + & 001 \\
\hline Kosten 3 & 2014 & 4.38 & \pm & 0.19 & 0.53 & \pm & 0.02 & 87.94 & \pm & 0.22 & Red & 0.20 & \pm & 0.01 \\
\hline & 2015 & 4.02 & \pm & 0.16 & 0.51 & \pm & 0.02 & 87.15 & \pm & 0.67 & - & & & \\
\hline & 2012 & 3.38 & \pm & 0.11 & 0.44 & \pm & 0.02 & 86.9 & \pm & 0.7 & - & & & \\
\hline Krupnoplodni NS & 2013 & 4.24 & \pm & 0.22 & 0.58 & \pm & 0.02 & 86.09 & \pm & 0.37 & Dark & & & \\
\hline & 2014 & 3.72 & \pm & 0.09 & 0.48 & \pm & 0.01 & 87.07 & \pm & 0.4 & Red & 0.23 & \pm & 0.02 \\
\hline & 2015 & 4.03 & \pm & 0.1 & 0.51 & \pm & 0.02 & 87.35 & \pm & 0.42 & - & & & \\
\hline & 2012 & 5.01 & \pm & 0.23 & 0.61 & \pm & 0.03 & 87.63 & \pm & 0.79 & - & & & \\
\hline Lukvanoyskiv & 2013 & 5.27 & \pm & 0.22 & 0.65 & \pm & 0.03 & 87.72 & \pm & 0.55 & - & 014 & + & 001 \\
\hline & 2014 & 4.44 & \pm & 0.14 & 0.56 & \pm & 0.03 & 87.41 & \pm & 0.35 & Red & 0.14 & \pm & 0.01 \\
\hline & 2015 & 4.33 & \pm & 0.26 & 0.52 & \pm & 0.02 & 87.79 & \pm & 0.52 & - & & & \\
\hline Vladimirskiv & 2014 & 5.01 & \pm & 0.17 & 0.57 & \pm & 0.02 & 88.58 & \pm & 0.37 & - & 021 & + & 003 \\
\hline Vladimirskiy & 2015 & 6.16 & \pm & 0.23 & 0.57 & \pm & 0.02 & 90.59 & \pm & 0.55 & Red & 0.21 & \pm & 0.03 \\
\hline$F_{\text {genotype }}, p_{\text {genotype }}$ & - & 126.3 & $p$ & 0.001 & 29.51 & $p<$ & 0.001 & 73.53, & $p<$ & 0.001 & & $26, p=$ & 0.006 & \\
\hline$F_{\text {year }}, p_{\text {year }}$ & - & 44.5 & $p$ & 0.001 & 32.76 & $p<$ & 0.001 & 14.29, & $p<$ & 0.001 & & - & & \\
\hline 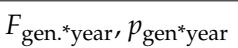 & - & 3.18 & $p<$ & 0.001 & 3.63 & $p<$ & .001 & 2.78, & $<<0$ & .001 & & - & & \\
\hline
\end{tabular}


The weight of the fruit varied widely from $1.89 \pm 0.04 \mathrm{~g}$ in 2012 in the selection Boro to $6.16 \pm$ $0.23 \mathrm{~g}$ in 2015 in the variety Vladimirskiy. Apatinski rani had the smallest stone, weighting $0.32 \pm$ $0.02 \mathrm{~g}$ (in 2015), while the largest stone was observed in the variety Lukyanovskiy, $0.65 \pm 0.03 \mathrm{~g}$ (in 2013). The percentage of mesocarp in relation to the total weight of the fruit varied from $76.66 \pm 0.87 \%$ in the selection Boro in 2012 to $90.59 \pm 0.55 \%$ in 2015 for the Vladimirskiy variety. Measured fruit morphological characteristics of fruit weight, stone weight and the mesocarp content are significantly interacting with the climatic conditions throughout the years of the research (Table 2).

The data obtained on fruit and stone weight are generally similar to the previously published data $[8,10,13,18]$ which included different varieties and selection of cornelian cherry in different parts of world. Fruit weight is one of the main goals of cornelian cherry selection, because it is strongly positively correlated with the percentage of mesocarp in the total fruit weight [32] (Bijelić et al., 2007). This statement was confirmed in this study, and the fruits of the Vladimirskiy variety had the highest fruit weight and the share of mesocarp in the fruit, while the fruits of the Boro selection had the lowest weight and the lowest yield of mesocarp. Apart from the genetic constitution, the share of mesocarp is also significantly influenced by environmental factors, and there are variations in different years of research, which were also noted by Bjelić et al. [33]. Ninić-Todorović et al. [34] (2005) point out that the share of mesocarp higher than $75 \%$ of the total fruit weight is favorable from the point of view of processing in order to obtain confectionery products. Apart from the Boro selection, all other studied varieties and selections have fruits with a high yield of mesocarp, above $80 \%$, which has a positive effect on their economic value. The data for this parameter presented in this paper are in ranges stated by other authors [12,34-36].

In order to observe and present patterns of the most important fruit characteristic, namely fruit weight and flesh content, it is presented (Figure 1) throughout the years of research.

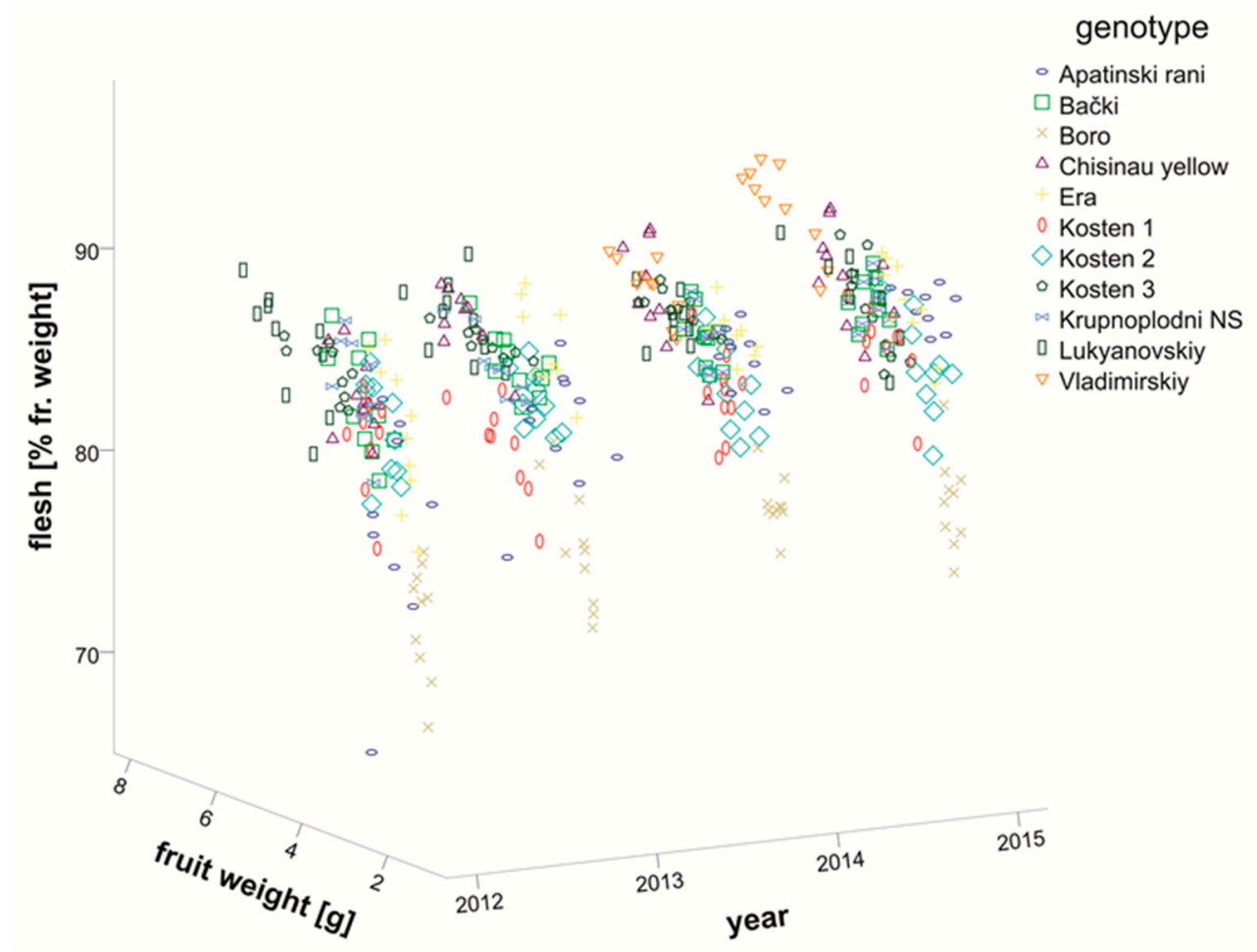

Figure 1. Individual measured fruit characteristics of studied Cornelian cherry genotypes in years of study.

It is clear that genotypes Vladimirskiy, Chisinau yellow, and Lukyanovskiy consistently had larger fruit with more fruit flesh than other studied genotypes. Second best come local varieties Kosten 3, Bačka, and, in some years, Krupnoplodni NS. Smallest fruit with small flesh content is 
consistently produced by genotype Boro. In this category with small fruit also belong Kosten 1, Kosten 2, and Apatinski rani. It can be noted that fruit size was generally larger in year 2013 in comparison to other years of study. Measured fruit morphological characteristics of fruit weight, pit weight, and the flesh content are significantly interacting with the climatic conditions throughout the years of the research. The fruits of most examined varieties and selections had a dark red and red color, while yellow color was observed in the fruits of the Chisinau yellow variety and the Boro selection. Color, as an organoleptic property, affects the consumer acceptability of fruits, and red and dark red cherries are in higher demand due to the attractiveness [37]. Dokoupil and Rezniček [38] consider that red color is characteristic of cornelian cherry fruits, although pink and yellow fruits can be found. Jaćimović and Božović [39] state that, when unripe cornelian cherry fruits are marinated like olives in saline solution, the final product is of better quality if yellow fruits are used, while it is better to use red fruits for processing into jam, juice, and liqueur.

\subsection{Yield}

Productivity is a property that directly affects the economics of cornelian cherry production. The lowest yield efficiency $(0.10)$ was found in the selection Boro, while the highest $(0.23)$ was observed in the selection Krupnoplodni NS. In addition to the selection of Krupnoplodni NS, the Vladimirskiy and Chisinau yellow varieties had a high yield, as did the Kosten 1 and Kosten 3 selections. Yield efficiency above 0.15 indicates good yield [28]. Cultivars, rootstocks, environmental conditions, and applied cultivation techniques significantly affect productivity of fruit trees [40].

Genotypes significantly $(p=0.006)$ differ in yield efficiency (Table 2$)$. For better visualization of the agronomical traits important to the yield, i.e., yield per TCSA and fruit weight data is presented in combination as measured in the years of study (Figure 2). The best genotypes are Vladimirskiy, Chisinau yellow and Krupnoplodni NS characterized with consistently higher yield and large fruit. Good yield and good-sized fruit are measured also in local genotype Kosten 3 and Bačka. Genotype Boro had consistently the lowest yield with the smallest fruit.

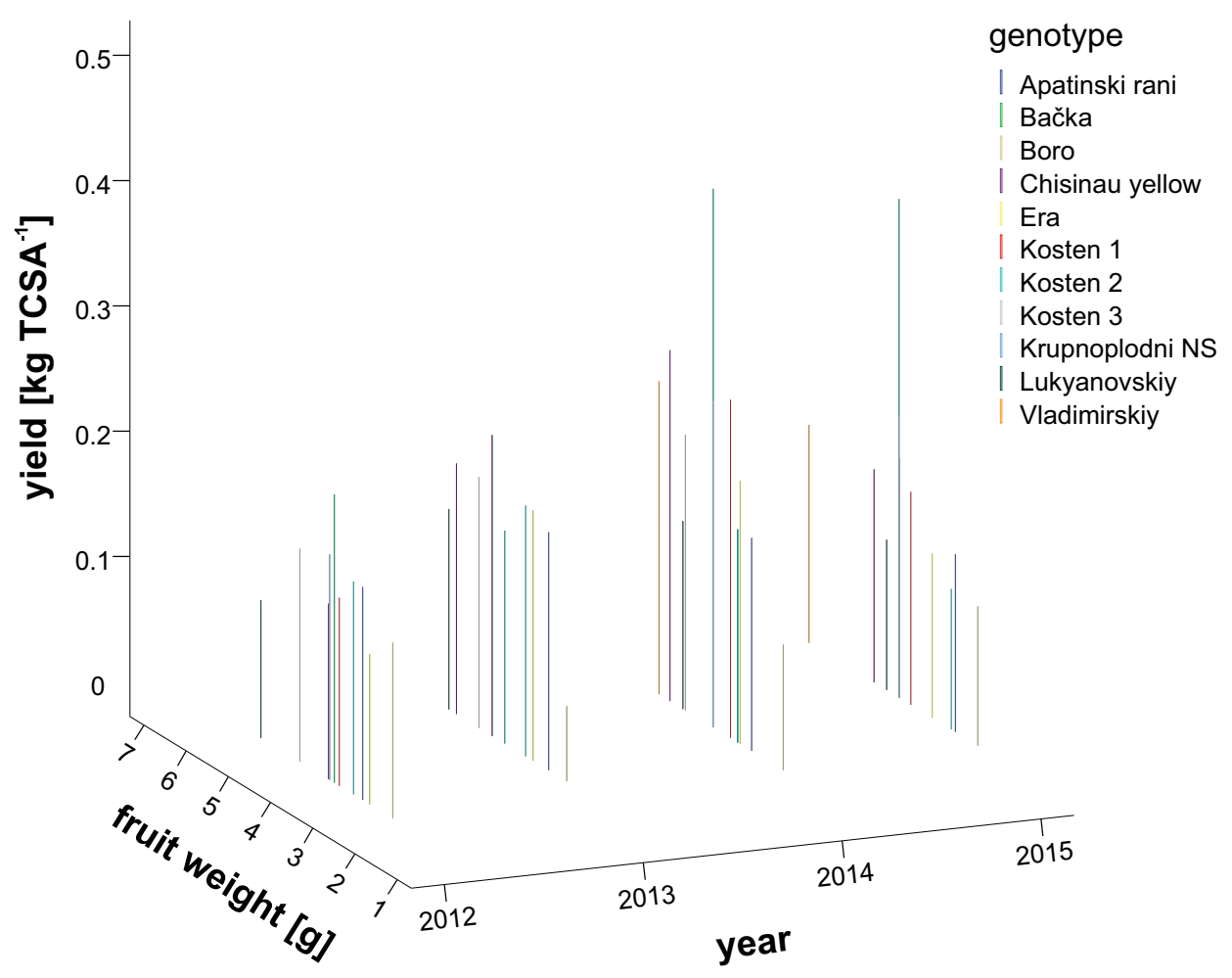

Figure 2. Mean fruit weight and yield of studied Cornelian cherry genotypes in years of study. 


\subsection{Biochemical Characteristics}

Biochemical analyses of varieties and selection of cornelian cherry included the chemical characteristics of the fruit, as well as the content of certain mineral substances, in a four-year period. The chemical characteristics of the fruit are shown in Table 3. The minimal content of dry matter (TDM) was determined in the fruits of the cultivar Chisinau yellow $19.81 \%$, and the maximal $24.46 \%$ in the fruits of the selection Krupnoplodni NS presented in Table 2. Similar data for the TDM parameter in fruits of different varieties and genotypes of Cornelian cherry were presented by Tural and Koca [41] as 15.9-28.2\% and by Sengul et al. [42] (2014) as 18-23.3\% in Turkey, Maghradze et al. [43] reported 17.7-26.1\% in Georgia and Jaćimović et al. [14] reported 18.8-27.7\% in Montenegro. For the same parameter, slightly higher values were presented by Bijelić et al. [36] as 18.3-33.4\% in Serbia. The amount of TDM in Cornelian cherry fruit is significantly influenced by genetic constitution, age, cultivation system, applied agricultural techniques, climatic, and soil factors, as well as the degree of fruit maturity at harvest $[18,44]$.

Cornelian cherry fruit has a significant energy value, mostly due to the abundance of sugar, which dominates the dry matter. Sugar content is the main parameter that affects not only the direct consumption of fruit, but also the fermentation processes during various types of processing. Highest amount of total and reducing sugars had selection Kosten 110.94 and $10.44 \%$. Sucrose content ranged from $0.24 \%$ (Kosten 2) to $1.23 \%$ (Krupnoplodni NS). Similar results on total sugar content in Cornelian cherry fruit were presented by Tural and Koca [41] in Turkey 7.7-15.4\% and Brindza et al. [45] in Slovakia as $6.5-15.1 \%$. Compared to the presented data for total sugars, Bijelić et al. [36] found a higher amount of total sugars, $13.49-25.23 \%$ in cornelian cherry fruits from Serbia, while Maghradze et al. [43] and Drkenda et al. [46] observed lower values in fruits from Georgia and Bosnia and Herzegovina, respectively, which ranged from 6.2 to $9.2 \%$. The determined differences in the content of total sugars can be interpreted as a result of different climatic and soil conditions.

The reducing sugars contained in the cornelian cherry fruits from Poland examined by Kucharska et al. [47] were 9.9-14.7\%, and in the cornelian cherry fruits from Turkey measured by Sengul et al. [42] as 8.6-15.2\%, which is in accordance with our research. The low amount of sucrose in the studied fruits confirmed the conclusion of Kucharska et al. [47] that reducing sugars make the main part of total sugars in cornelian cherry fruits (about 90\%). Akagić et al. [48] believe that the lower sucrose content can be explained by the high activity of invertase in the final stage of fruit ripening. The acidity of cornelian cherry fruit occurs due to the presence of organic acids, of which malic acid predominates [46]. The total acidity in these studies varied from $1.92 \%$ in the Boro selection to $2.51 \%$ in the Vladimirskiy variety. Similar data for total acidity in cornelian cherry fruit, which ranged from 1.1 to 3.7, were presented by Klimenko et al. [49]; Tural and Koca [41]; Maghradze et al. [43]; Ercisli et al. [37]; and Bijelić et al. [36]. The processes involved in the metabolism and accumulation of malic and citric acid in mesocarp cells are under genetic and environmental control [50]. Pectic substances are dietary fibres of high nutritional value. The lowest amount of pectin was in the fruits of the Era selection $2.76 \%$, and the highest in the fruits of the Bačka selection $4.43 \%$. Lower results than ours on the content of pectic substances in Cornelian cherry fruit, from 0.37 to $2.47 \%$, were presented by Maghradze et al. [43]; Bijelić et al. [36]; Jaćimović et al. [9], which can be explained by the high dependence of this parameter on the environmental factors. In years when the air temperature is high during ripening, and the amount of precipitation is low, an increased content of pectic substances in the fruit can be expected [9]. Pectins have the property that in the presence of sugars and acids are transformed into a gelatinous mass called jelly, which is especially used in the fruit processing industry [51].

Vitamins are essential nutrients that the human body cannot synthesize, but consumes through food. Vitamin C strengthens the immune system and as an antioxidant plays a protective role against cardiovascular diseases [6]. Cornelian cherry fruits contain more vitamin $C$ than fruits of many other fruit species that are considered to be rich sources of this vitamin, e.g., strawberries, kiwis, lemons, oranges, etc. $[15,26,52]$. Fruits of the varieties and selection of cornelian cherry presented in this paper 
had vitamin C from $41.09 \mathrm{mg} / 100 \mathrm{~g}$ (Lukyanovskiy) to $101.27 \mathrm{mg} / 100 \mathrm{~g}$ (Kosten 3). In accordance with our data, the results on the content of this vitamin presented by Yilmaz et al. [35] (2009) as 29-112 mg/100 g and Maghradze et al. [43] as 50.5-128 mg/100 g. Cornelian cherry fruits are often used in the processed state without the application of heat treatment so that vitamin $\mathrm{C}$, as well as other thermo labile substances, remain preserved in the final product [39].

Anthocyanins are natural nutritive bioactive components that are found in fruits and have a beneficial effect on human health. They are among the most important bioactive compounds that prevent cardiovascular disease and cancer, which are considered the most common diseases today [53-55]. The fruits of selection Kosten 1 with a content of $157.06 \mathrm{mg} / 100 \mathrm{~g}$ were the most abundant in total anthocyanins of all studied varieties and selections. In the fruits of the Chisinau yellow variety and the Boro selection, anthocyanins were not determined, which confirms the statement made by Ochmian et al. [56] that genotypes that have a yellow skin color do not contain anthocyanin compounds in the fruit. The concentration of anthocyanins in fruit varieties tested by Kucharska et al. [47] ranged from 33.7 to $149.6 \mathrm{mg} / 100 \mathrm{~g}$ and Bijelić et al. [37] from 37.6 to $116.4 \mathrm{mg} / 100 \mathrm{~g}$, which is consistent with the data presented in this paper. Kazimierski et al. [26] indicate that according to the literature, the total content of anthocyanins in cornelian cherry fruits is between 35 and $300 \mathrm{mg} / 100 \mathrm{~g}$, depending on the color of the epidermis, which varies from pink to dark red.

Phenolic compounds are very widespread products of secondary metabolism of plants, which are recently receiving great attention. They are found in significant quantities in food products of plant origin, and numerous studies indicate that their regular consumption reduces the risk of many serious diseases $[57,58]$. Cornelian cherry fruits contain significant amounts of phenolic bioactive substances, which contribute to their antioxidant value. In our study, the lowest total polyphenols were found in the fruits of the Chisinau yellow variety $183.91 \mathrm{mg} / 100 \mathrm{~g}$, and the highest in the fruits of the selection Krupnoplodni NS $307.9 \mathrm{mg} / 100 \mathrm{~g}$. The content of total polyphenols in Cornelian cherry fruits from Bosnia and Herzegovina studied by Drkenda et al. [46] ranged from 119.1 to $230.6 \mathrm{mg} \mathrm{GAE} / 100 \mathrm{~g}$ FW, and in fruits from Romania shown by Cosmulenca et al. [59] from 163.7 to $359.28 \mathrm{mg} \mathrm{GAE} / 100 \mathrm{~g}$ FW, which is close to results presented in this paper. Much wider variation in the content of total polyphenols in Cornelian cherry fruits was presented by Stanković et al. [60] from 12.8 to $341.1 \mathrm{mg}$ $\mathrm{GAE} / 100 \mathrm{~g}$ FW. In addition to the genetic constitution, the amount of phenolic compounds in fruits is influenced by climatic and geographical factors, applied agro technics, and fruit ripeness.

The most important source of minerals in the diet is food of plant origin, which is also biologically more valuable. According to the presented research, the total amount of ash ranged from $0.89 \%$ (Lukyanovskiy) to $1.16 \%$ (Bačka). A smaller amount of mineral substances ranging from 0.61 to $0.81 \%$ had genotypes of the Cornelian cherry fruits from Turkey studied by Sengul et al. [42] and in accordance with our results, Cornelian cherry genotypes from Montenegro had mineral substances content from 0.65 to $1.59 \%$ [9] and from Serbia 0.53-1.23\% [36].

\subsection{Content of Certain Mineral Substances in the Fruit}

The content of the most important mineral substances in the fruits of the studied varieties and selections is presented in Table 4. Potassium is the dominant mineral element in the fruit of cornelian cherry $[16,61]$. From the presented data, it can be noted that the variety Chisinau yellow has the lowest content of potassium in the fruit $2888 \mathrm{mg} / \mathrm{kg}$, while the fruits of the selection Kosten 1 demonstrate good supply of this important element $3574 \mathrm{mg} / \mathrm{kg}$. Dokoupil and Rezniček [38] reported that Cornelian cherry fruit content of potassium is in the range from 3441 to $3798 \mathrm{mg} / \mathrm{kg}$, and Gozlekci et al. [16] report potassium content ranges from 2780 to $3340 \mathrm{mg} / \mathrm{kg}$, which is close to data presented in this paper. Potassium regulates the normal function of the nervous system, heart and other muscles. An important function of potassium as an electrolyte is to maintain the acid-base balance in human body, and an adequate supply of this macroelement prevents acidification of the body. Eating fruits that are rich in potassium can reduce blood pressure, and it is recommended for people suffering from hypertension [62]. 
Table 3. Chemical characteristics in the fruit of studied Cornelian cherry genotypes fruit (mean \pm standard error) with statistical analysis indicating statistically significant differences between the genotypes ( $F$ and $p$ values).

\begin{tabular}{|c|c|c|c|c|c|c|c|c|c|c|c|c|c|c|c|c|c|c|c|c|c|c|c|c|c|c|c|c|c|c|}
\hline \multirow[t]{2}{*}{ Genotype } & \multicolumn{3}{|c|}{$\begin{array}{l}\text { DM } \\
(\%)\end{array}$} & \multicolumn{3}{|c|}{$\begin{array}{l}\text { Total Sugars } \\
\text { (TS) } \\
\text { (\%) }\end{array}$} & \multicolumn{3}{|c|}{$\begin{array}{c}\text { Reducing } \\
\text { Sugars (RS) } \\
(\%)\end{array}$} & \multicolumn{3}{|c|}{$\begin{array}{c}\text { Sucrose } \\
(\%)\end{array}$} & \multicolumn{3}{|c|}{$\begin{array}{l}\text { Total Acids } \\
\text { (TA) } \\
\text { (\%) }\end{array}$} & \multicolumn{3}{|c|}{$\begin{array}{c}\text { Ca-Pectate } \\
(\%)\end{array}$} & \multicolumn{3}{|c|}{$\begin{array}{l}\text { Vitamin C } \\
(\mathrm{mg} / 100 \mathrm{~g})\end{array}$} & \multicolumn{3}{|c|}{$\begin{array}{l}\text { Anthocyanins } \\
\text { (mg/100 g) }\end{array}$} & \multicolumn{3}{|c|}{$\begin{array}{l}\text { Polyphenols } \\
\text { (mg/100 g) }\end{array}$} & \multicolumn{3}{|c|}{$\begin{array}{l}\text { Ash } \\
(\%)\end{array}$} \\
\hline & $\bar{x}$ & \pm & $\mathrm{S} \overline{\mathbf{x}}$ & $\bar{x}$ & \pm & $\mathrm{S} \overline{\mathrm{x}}$ & $\bar{x}$ & \pm & $S \bar{x}$ & $\bar{x}$ & \pm & $\mathrm{S} \overline{\mathbf{x}}$ & $\bar{x}$ & \pm & $\mathrm{S} \overline{\mathbf{x}}$ & $\bar{x}$ & \pm & $\mathrm{S} \overline{\mathbf{x}}$ & $\bar{x}$ & \pm & $\mathrm{S} \overline{\mathbf{x}}$ & $\bar{x}$ & \pm & $S \overline{\mathbf{x}}$ & $\bar{x}$ & \pm & $\mathrm{S} \overline{\mathbf{x}}$ & $\bar{x}$ & \pm & $\mathrm{S} \overline{\mathbf{x}}$ \\
\hline Apatinski rani & 24.36 & \pm & 1.37 & 14.47 & \pm & 0.45 & 12.64 & \pm & 0.33 & 0.49 & \pm & 0.10 & 2.31 & \pm & 0.34 & 4.20 & \pm & 0.31 & 61.10 & \pm & 6.89 & 100.44 & \pm & 4.42 & 208.55 & \pm & 20.88 & 1.15 & \pm & 0.16 \\
\hline Bačka & 1.68 & \pm & 1.48 & 12.94 & \pm & 0.78 & 12.10 & \pm & 1.02 & 0.60 & \pm & 0.2 & 2.12 & \pm & & 4.43 & \pm & 0.90 & 57.78 & \pm & 5.77 & 32.54 & \pm & 5.86 & 216.25 & \pm & 20.40 & 1.16 & \pm & 0.20 \\
\hline Boro & 21.17 & \pm & 2.05 & 12.42 & \pm & 1.58 & 11.90 & \pm & 1.57 & 0.37 & \pm & 0.09 & 2.51 & \pm & 0.02 & 3.13 & \pm & 0.46 & 89.64 & \pm & 5.79 & & - & & 265.95 & \pm & 7.79 & 1.07 & \pm & 0.16 \\
\hline Era & 1.58 & \pm & 1.53 & 11.79 & \pm & 1.32 & 11.26 & \pm & 1.16 & 0.35 & \pm & 0.05 & 2.29 & \pm & 0.24 & 2.76 & \pm & 0.49 & 79.83 & \pm & 2.42 & 65.23 & \pm & 8.25 & 233.09 & \pm & 19.99 & 1.02 & \pm & 0.18 \\
\hline Chisinau yellow & 19.81 & \pm & 1.28 & 12.83 & \pm & 1.02 & 12.38 & \pm & 0.91 & 0.45 & \pm & 0.11 & 2.06 & \pm & 0.03 & 2.98 & \pm & 0.56 & 58.14 & \pm & 6.33 & & - & & 183.91 & \pm & 5.47 & 1.08 & \pm & 0.25 \\
\hline & & \pm & 1.22 & 10.94 & \pm & 0.52 & 10.44 & \pm & 0.54 & & \pm & 0.04 & 2.37 & \pm & 0.19 & & \pm & 0.45 & 101.27 & \pm & 3.39 & 157.06 & \pm & 32.87 & 255.80 & \pm & 44.27 & 1.14 & \pm & 0.07 \\
\hline Kosten 2 & 24.45 & \pm & 2.30 & 13.26 & \pm & 0.54 & 12.62 & \pm & 0.53 & 0.24 & \pm & 0.03 & 2.08 & \pm & 0.16 & 4.13 & \pm & 0.28 & 86.41 & \pm & 4.73 & 60.05 & \pm & 2.06 & 258.21 & \pm & 38.95 & 1.09 & \pm & 0.09 \\
\hline Kosten 3 & 23.83 & \pm & 1.65 & 14.07 & \pm & 1.59 & 13.09 & \pm & 1.26 & 0.92 & \pm & 0.33 & 2.02 & \pm & 0.21 & 4.18 & \pm & 1.00 & 64.52 & \pm & 2.72 & 104.09 & \pm & 38.52 & 219.15 & \pm & 12.57 & 0.94 & \pm & 0.29 \\
\hline Krupnoplodni N & 25.46 & \pm & 1.76 & 12.47 & \pm & 0.33 & 11.17 & \pm & 0.60 & 1.23 & \pm & 0.27 & 2.15 & \pm & 0.25 & & \pm & 0.70 & 65.11 & \pm & 2.88 & 80.07 & \pm & 17.50 & 307.90 & \pm & 23.99 & 1.14 & \pm & 0.07 \\
\hline Lukyanovskiy & 20.58 & \pm & 0.40 & 13.53 & \pm & 0.28 & 12.87 & \pm & 0.29 & 0.63 & \pm & 0.19 & 2.28 & \pm & 0.11 & 3.45 & \pm & 1.02 & 41.09 & \pm & 12.79 & 47.88 & \pm & 12.09 & 217.44 & \pm & 9.02 & 0.89 & \pm & 0.13 \\
\hline Vladimirskiy & 21.45 & \pm & 1.12 & 12.90 & \pm & 0.20 & 11.80 & \pm & 0.25 & 0.90 & \pm & 0.01 & 1.92 & \pm & 0.13 & 3.43 & \pm & 1.12 & 72.40 & \pm & 5.10 & 59.26 & \pm & 2.14 & 243.75 & \pm & 13.55 & 1.08 & \pm & 0.09 \\
\hline$F_{\text {genotype, }}, p_{\text {genotype }}$ & \multicolumn{3}{|c|}{$1.1, p=0.459$} & \multicolumn{3}{|c|}{$0.8, p=0.605$} & \multicolumn{3}{|c|}{$0.6, p=0.780$} & \multicolumn{3}{|c|}{$2.1, p=0.073$} & \multicolumn{3}{|c|}{$0.5, p=0.868$} & \multicolumn{3}{|c|}{$0.5, p=0.840$} & \multicolumn{3}{|c|}{$6.2, p<0.001$} & \multicolumn{3}{|c|}{$5.3, p=0.001$} & \multicolumn{3}{|c|}{$1.6, p=0.177$} & \multicolumn{3}{|c|}{$0.2, p=0.994$} \\
\hline
\end{tabular}


In the fruits of the tested varieties and selection of Cornelian cherry, other macroelements were present in the following amounts: Na from $4.99 \mathrm{mg} / \mathrm{kg}$ (Kosten 3) to $32.3 \mathrm{mg} / \mathrm{kg}$ (Boro), Ca from $239.6 \mathrm{mg} / \mathrm{kg}$ (Lukyanovskiy) to $444.6 \mathrm{mg} / \mathrm{kg}$ (Boro), $\mathrm{Mg}$ from $70.7 \mathrm{mg} / \mathrm{kg}$ (Chisinau yellow) to $165 \mathrm{mg} / \mathrm{kg}$ (Krupnoplodni NS) and P from $179 \mathrm{mg} / \mathrm{kg}$ (Kosten 2) to $221.6 \mathrm{mg} / \mathrm{kg}$ (Bačka). Sodium has an important role in maintaining fluid balance in the body. Sodium and potassium are closely related, because the first element is an antagonist of the second, which means that it has the opposite action. Balance between these two electrolytes is necessary to maintain homeostasis throughout the body [16]. Compared to our data, cornelian cherry genotypes examined by Dokoupil and Rezniček [38] (2012) and Gozlekci et al. [16] had a higher amount of sodium in the fruit $51-82 \mathrm{mg} / \mathrm{kg}$. In cornelian cherry fruits, Sotiropoulos et al. [8] showed lower concentrations of biogenic elements compared to those presented in this paper Ca 20-30 mg/kg, Mg 40-50 mg/kg and P 80-90 mg/kg, and Bjelić et al. [36] found higher variation in Ca content from 24.7 to $526 \mathrm{mg} / \mathrm{kg}$ and $\mathrm{Mg}$ from 10.12 to $160 \mathrm{mg} / \mathrm{kg}$. Sufficient amount of phosphorus and calcium in the diet enables proper functioning of bones and teeth, muscle and heart. Magnesium is essential for the proper metabolic processes, as well as the normal functioning of the neuromuscular and cardiovascular systems [16].

Tested varieties and selections of cornelian cherry contained in fruits important microelements in following concentrations: Fe from $3.85 \mathrm{mg} / \mathrm{kg}$ (Kosten 1), to $14.21 \mathrm{mg} / \mathrm{kg}$ (Vladimirskiy), Zn from $1.17 \mathrm{mg} / \mathrm{kg}$ (Kosten 1) to $3.05 \mathrm{mg} / \mathrm{kg}$ (Era), Cu from $1 \mathrm{mg} / \mathrm{kg}$ (Kosten 2) to $1.27 \mathrm{mg} / \mathrm{kg}$ (Krupnoplodni NS), and Mn from $2.27 \mathrm{mg} / \mathrm{kg}$ (Chisinau yellow) to $5.40 \mathrm{mg} / \mathrm{kg}$ (Kosten 1). Slightly lower amounts of these trace elements were found in Cornelian cherry genotypes presented by Bijelić et al. [36], much lower in cultivars studied by Sotiropoulos et al. [8], and higher in genotypes studied by Gozlekci et al. [16]. This variability is conditioned by genotype, climate, soil and geographical factors, substrate used, etc.

Analysis of biochemical characteristics indicated statistically highly significant differences among studied genotypes in $\mathrm{Na}, \mathrm{Mg}, \mathrm{P}, \mathrm{Fe}, \mathrm{Zn}, \mathrm{Mn}$, vitamin $\mathrm{C}$, and anthocyanins $(p<0.001)$ content, while there was no observed statistically significant difference $(p>0.07)$ in $\mathrm{K}, \mathrm{Ca}, \mathrm{Cu}, \mathrm{TDM}$, ash, TA, total sugars (TS), reducing sugars (RS), sucrose, Ca-pectate, and polyphenols (Tables 3 and 4). 
Table 4. Mineral contents $(\mathrm{mg} / \mathrm{kg})$ in the fruit of studied Cornelian cherry genotypes fruit (mean \pm standard error) with statistical analysis indicating statistically significant differences between the genotypes ( $F$ and $p$ values).

\begin{tabular}{|c|c|c|c|c|c|c|c|c|c|c|c|c|c|c|c|c|c|c|c|c|c|c|c|c|c|c|c|}
\hline \multirow{2}{*}{ Genotype } & \multicolumn{3}{|c|}{$\mathbf{K}$} & \multicolumn{3}{|c|}{$\mathrm{Na}$} & \multicolumn{3}{|c|}{$\mathrm{Ca}$} & \multicolumn{3}{|c|}{$\mathrm{Mg}$} & \multicolumn{3}{|c|}{$\mathbf{P}$} & \multicolumn{3}{|c|}{$\mathrm{Fe}$} & \multicolumn{3}{|c|}{$\mathrm{Zn}$} & \multicolumn{3}{|c|}{$\mathrm{Cu}$} & \multicolumn{3}{|c|}{ Mn } \\
\hline & $\bar{X}$ & \pm & $\mathrm{S} \overline{\mathbf{x}}$ & $\bar{X}$ & \pm & $S \bar{x}$ & $\bar{x}$ & \pm & $S \bar{x}$ & $\bar{X}$ & \pm & $S \bar{x}$ & $\bar{X}$ & \pm & $S \bar{x}$ & $\bar{X}$ & \pm & $S \bar{x}$ & $\bar{x}$ & \pm & $S \bar{x}$ & $\bar{X}$ & \pm & $S \bar{x}$ & $\bar{x}$ & \pm & $S \bar{x}$ \\
\hline Apatinski rani & 3136 & \pm & 206 & 16 & \pm & 1.23 & 320 & \pm & 14.1 & 113.3 & \pm & 4.35 & 200 & \pm & 2 & 4.5 & \pm & 0.31 & 1.79 & \pm & 0.09 & 1.01 & \pm & 0.14 & 5.13 & \pm & 0.53 \\
\hline Bačka & 3380 & \pm & 106 & 18.5 & \pm & 3.17 & 310.9 & \pm & 29.5 & 108.5 & \pm & 8.77 & 221.6 & \pm & 2.5 & 5.17 & \pm & 0.11 & 1.84 & \pm & 0.23 & 1.04 & \pm & 0.25 & 4.2 & \pm & 0.18 \\
\hline Boro & 3136 & \pm & 128 & 32.3 & \pm & 1.55 & 444.6 & \pm & 5.52 & 130.2 & \pm & 6.74 & 202.5 & \pm & 5.82 & 4.1 & \pm & 0.09 & 1.52 & \pm & 0.04 & 1.15 & \pm & 0.07 & 4.2 & \pm & .49 \\
\hline Era & 3009 & \pm & 83 & 20.1 & \pm & 0.51 & 402.1 & \pm & 37.1 & 105.6 & \pm & 7.74 & 206.1 & \pm & 3.77 & 7.87 & \pm & 2.97 & 3.05 & \pm & 0.12 & 1.26 & \pm & 0.12 & 3.67 & \pm & 0.08 \\
\hline Chisinau yellow & 2885 & \pm & 34.4 & 20.4 & \pm & 0.33 & 315.9 & \pm & 50.7 & 70.07 & \pm & 6.58 & 192.5 & \pm & 1.53 & 4.98 & \pm & 0.04 & 1.38 & \pm & 0.22 & 1.07 & \pm & 0.08 & 2.27 & \pm & 0.08 \\
\hline Kosten 1 & 3574 & \pm & 46 & 15.9 & \pm & 2.1 & 312.8 & \pm & 3.96 & 122.1 & \pm & 8.09 & 192.4 & \pm & 3.2 & 4.37 & \pm & 0.12 & 1.41 & \pm & 0.13 & 1.16 & \pm & 0.04 & 5.4 & \pm & 0.57 \\
\hline Kosten 2 & 3452 & \pm & 257 & 16.5 & \pm & 1.31 & 293.7 & \pm & 12.3 & 84.82 & \pm & 2.34 & 179 & \pm & 3.9 & 5.1 & \pm & 0.44 & 1.7 & \pm & 0.27 & 1 & \pm & 0.04 & 4.63 & \pm & 0.32 \\
\hline Kosten 3 & 3259 & \pm & 118 & 4.99 & \pm & 0.25 & 326.3 & \pm & 63.8 & 99.77 & \pm & 12.6 & 203.2 & \pm & 5.25 & 3.85 & \pm & 0.55 & 1.17 & \pm & 0.19 & 1.09 & \pm & 0.08 & 2.37 & \pm & 0.08 \\
\hline Krupnoplodni NS & 3461 & \pm & 101 & 25.9 & \pm & 1.49 & 301.4 & \pm & 20.9 & 165 & \pm & 6.03 & 182.7 & \pm & 9.39 & 4.2 & \pm & 0.22 & 1.86 & \pm & 0.09 & 1.27 & \pm & 0.21 & 3.53 & \pm & 0.19 \\
\hline Lukyanovskiy & 3193 & \pm & 98.5 & 11.6 & \pm & 0.86 & 239.6 & \pm & 33.3 & 77.49 & \pm & 7.4 & 206.6 & \pm & 4.21 & 4.61 & \pm & 0.71 & 1.88 & \pm & 0.17 & 1.04 & \pm & 0.11 & 2.9 & \pm & 0.22 \\
\hline Vladimirskiy & 3282 & \pm & 155 & 11.7 & \pm & 1.42 & 317 & \pm & 25.5 & 99.84 & \pm & 2.26 & 203.6 & \pm & 3.25 & 14.21 & \pm & 0.31 & 1.42 & \pm & 0.11 & 1.02 & \pm & 0.08 & 2.95 & \pm & 0.25 \\
\hline$F_{\text {genotype }}, p_{\text {genotype }}$ & \multicolumn{3}{|c|}{$1.7, p=0.134$} & \multicolumn{3}{|c|}{$17.2 ; p<0.001$} & \multicolumn{3}{|c|}{$2.1, p=0.071$} & \multicolumn{3}{|c|}{$9.8, p<0.001$} & \multicolumn{3}{|c|}{$5.1, p=0.001$} & \multicolumn{3}{|c|}{$5.2, p=0.001$} & \multicolumn{3}{|c|}{$6.9, p<0.001$} & \multicolumn{3}{|c|}{$0.4, p=0.923$} & \multicolumn{3}{|c|}{$8.1, p<0.001$} \\
\hline
\end{tabular}


By analyzing the all measured biochemical characteristics of studied Cornelian cherry genotypes through principal components analysis we have observed general influence of the year of study (Figure 3). Namely, in 2013, all genotypes grouped together along the negative part of the first principal component. This component is positively correlated with dry matter, anthocyanins, ash, and sugar content. Bearing in mind the larger fruit recorded for all genotypes in 2013, it can be linked to lower measures of those biochemical characteristics.
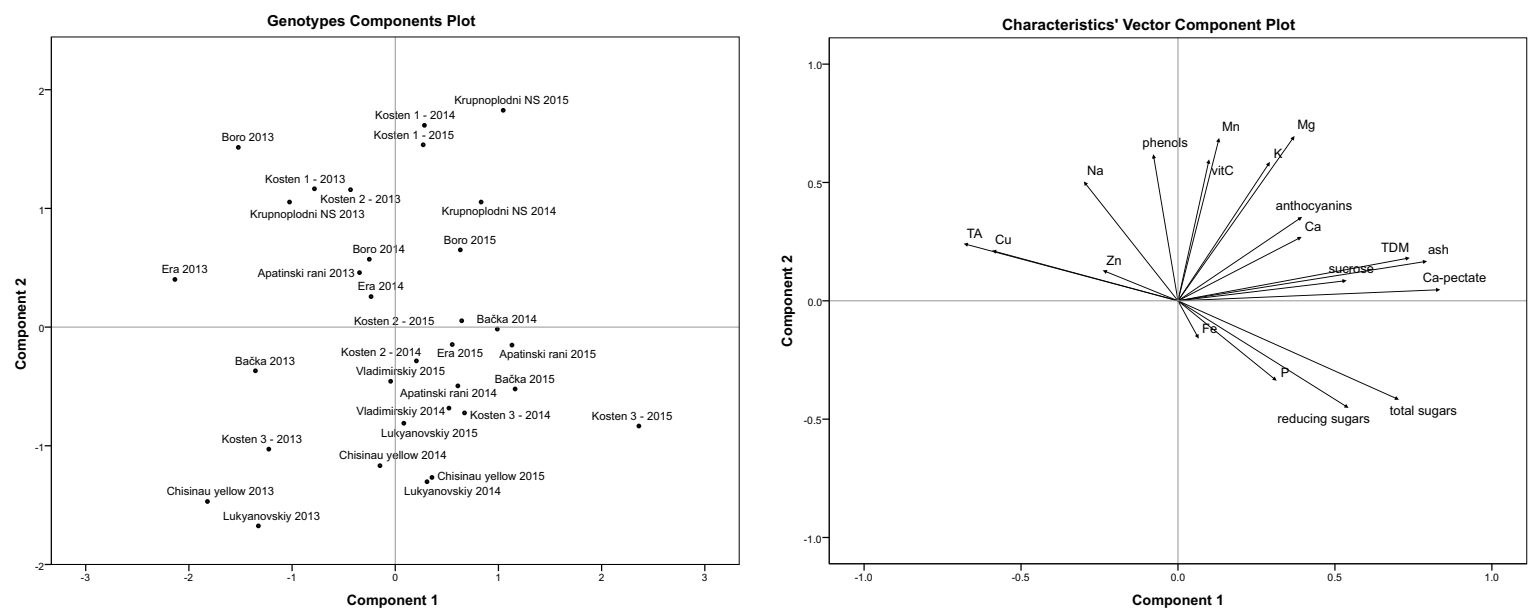

Figure 3. Principal components analysis of fruits biochemical characteristics of studied genotypes in years of study with both genotypes components plots (left) and the vectors of individual biochemical characteristics (right).

Another important grouping factor is $C$ vitamin and anthocyanin content. Generally larger fruiting varieties Vladimirskiy, Lukyanovskiy, Chisinau yellow, and selection Bačka have consistently measured lower content in those and also most other measured biochemical characteristics. Selection Kosten 3 has larger fruit but also has higher anthocyanins content. Highest anthocyianins and C vitamin content was recorded in selection Kosten 2, coupled with lowest sugar content in this genotype. Those genotypes are grouped along the negative part of the second principal component.

Krupnoplodni NS, Kosten 1, and Boro represent group of genotypes with consistently higher to medium biochemical content. Those genotypes are grouped along the positive part of the second principal component for all years of study.

The change in biochemical and other measured characteristics has to be observed through weather conditions during the growing seasons [63-65]. In 2013, the growing season provided optimum precipitation and temperatures [63]. Contrary to that season in 2014 and 2015, there were different climate extremes. Namely, in 2014, during the growing season, precipitations were at the decades' maximum with almost $50 \%$ more precipitations in comparison to the long-term average [64]. Contrary to 2014, in 2015, growing season was dry, with almost 50\% less precipitations than the long-term average [65]. Climate change as peaks in precipitation and temperature leading to floods and droughts in 2014 and 2015, respectively, have, to a large extent, similarly influenced the fruit size and quality of studied cornelian cherry genotypes. Namely, most genotypes grouped close for its biochemical characteristics in 2014 and 2015.

\section{Conclusions}

Studied cornelian cherry international and local varieties and selections have intrinsically mixed combination of fruit size, yield, and biochemical content characteristics. Those are further significantly influenced by climate and especially climate change extremes. In all studied varieties and selections, we found that climate conditions which favored larger fruit and yield generally led to lower content of important biochemicals. The extensiveness of the study leads, therefore, to several clear conclusions 
and recommendations. Consistently, the best balance of biochemical elements in combination with good yield and fruit size measurements is found in selection Krupnoplodi NS. If fruit size and yield are priority, then varieties and selections Vladimirskiy, Chisinau yellow, Kosten 3, and Krupnoplodni NS have a clear advantage over other genotypes. In environments and years with unfavorable conditions, it is expected to have smaller fruit with more concentrated biochemical content.

Author Contributions: Conceptualization, V.J. and D.B.; data curation, V.J., D.B. and B.B.; formal analysis, V.J., D.B. and B.B.; methodology, V.J., D.B. and B.B.; project administration, V.J., D.B., T.N.; visualization, T.N. and S.E.; writing-original draft, V.J., D.B., B.B., S.E. and T.N.; writing-review and editing, D.B., T.N. and S.E. All authors have read and agreed to the published version of the manuscript.

Funding: Ministry of Science of Montenegro and Ministry of Agriculture of the Czech Republic.

Acknowledgments: We would like to express our gratefulness to the Ministry of Science of Montenegro that recognized the importance of cornelian cherry as a fruit species so that projects No 01-549/2012 "Examination of biological-technological characteristics of varieties and selection of cornelian cherry (Cornus mas L.) in Montenegro for recommendations for plantation cultivation" had been financed. The cooperation and research were supported of the program no. 6.2.10 ref.: 51834/2017-MZE-17253, sub-program" National Program of Conservation and Utilization of Plant Genetic Resources and Agrobiodiversity" which are funded by the Ministry of Agriculture of the Czech Republic.

Conflicts of Interest: The authors declare that they have no conflict of interest.

\section{References}

1. Ercisli, S.; Akbulut, M.; Ozdemir, O.; Sengul, M.; Orhan, E. Phenolic and antioxidant diversity among persimmon (Diospyrus kaki L.) genotypes in Turkey. Int. J. Food Sci. Nutr. 2008, 59, 477-482. [CrossRef]

2. Ozkan, G.; Ercisli, S.; Zeb, A.; Agar, G.; Sagbas, H.I.; Ilhan, G.; Gundogdu, M. Some morphological and biochemical characteristics of wild grown Caucasian Whortleberry (Vaccinium arctostaphylos L.) genotypes from Northeastern Turkey. Not. Bot. Horti. Agrobot. 2019, 47, 378-383. [CrossRef]

3. Gecer, M.K.; Kan, T.; Gundogdu, M.; Ercisli, S.; Ilhan, G.; Sagbas, H.I. Physicochemical characteristics of wild and cultivated apricots (Prunus armeniaca L.) from Aras valley in Turkey. Genet. Resour. Crop Evol. 2020, 67, 935-945. [CrossRef]

4. Eyduran, S.P.; Ercisli, S.; Akin, M.; Beyhan, Ö.; Geçer, M.K. Organic acids, sugars, vitamin c, antioxidant capacity, and phenolic compounds in fruits of white (Morus alba L.) and black (Morus nigra L.) mulberry genotypes. J. Appl. Bot. Food Qual. 2015, 88, 134-138.

5. Ercisli, S.; Ipek, A.; Barut, E. SSR marker-based DNA fingerprinting and cultivar identification of olives (Olea europaea). Biochem. Genet. 2011, 49, 555-561. [CrossRef]

6. Szczepaniak, O.M.; Kobus-Cisowska, J.; Kusek, W.; Przeor, M. Functional properties of cornelian cherry (Cornus mas L.): A comprehensive review. Eur. Food Res. Technol. 2019, 245, 2071-2087. [CrossRef]

7. Vilotić, D.; Tucović, A.; Radošević, G. Comparative analysis of anatomical-technological properties of cornel tree (Cornus mas L.) and red dogwood (Cornus sanguinea L.). In Proceedings Books of 7 th Symposium on Flora of Southeastern Serbia and Neighbouring Regions; Bulgarian Botanical Society: Dimitrovgrad, Bulgaria, 2002; pp. 117-120.

8. Sotiropoulos, T.; Petridis, A.; Koutinas, N.; Therios, I. 'Ntoulia 1' and 'Ntoulia 2' cornelian cherries (Cornus mas). Hortscience 2011, 46, 955-957. [CrossRef]

9. Jaćimović, V.; Božović, Đ.; Ercisli, S.; Ognjanov, V.; Bosančić, B. Some fruit characteristics of selected cornelian cherries (Cornus mas L.) from Montenegro. Erwerbs Obstbau. 2015, 57, 119-124. [CrossRef]

10. Ercisli, S. A short review of the fruit germplasm resources of Turkey. Genet. Resour. Crop Evol. 2004, 51, 419-435. [CrossRef]

11. Sochor, J.; Jurikova, T.; Ercisli, S.; Mlcek, J.; Baron, M.; Balla, S.; Yilmaz, S.O.; Necas, T. Characterization of cornelian cherry (Cornus mas L.) genotypes-genetic resources for food production in Czech Republic. Genetika 2014, 46, 915-924. [CrossRef]

12. Hassanpour, H.; Hamiddoghli, Y.; Samizadeh, H. Some fruit characteristics of Iranian cornelian cherries (Cornus mas L.). Not. Bot. Horti. Agrobo. 2012, 40, 247-252. [CrossRef]

13. Bajic-Ljubicic, J.; Popovic, Z.; Matic, R.; Bojovic, S. Selected phenolic compounds in fruits of wild growing Cornus mas L. Indian J. Tradit. Know. 2018, 17, 91-96. 
14. Jaćimović, V.; Božović, Đ. Biological traits of cornelian cherry genotypes (Cornus mas L.) from teritory of Montenegro. Genetika 2014, 46, 427-436.

15. Seeram, N.; Schuzki, R.; Chandra, A.; Nair, M.G. Characterization, quantification and bioactivities of anthocyanins in Cornus species. J. Agric. Food Chem. 2002, 50, 2519-2523. [CrossRef]

16. Gozlekci, S.; Esringu, A.; Ercisli, S.; Eyduran, S.P.; Akin, M.; Božović, Đ.; Nehgreanu-Pirjol, T.; Sagbas, H.I. Mineral content of cornelian cherry (Cornus mas L.) fruits. Oxid. Commun. 2018, 40, 301-308.

17. Memedov, N.; Craker, L.E. Cornelian cherry: A prospective source for phytomedicine. Acta Hortic. 2002, 629, 83-86. [CrossRef]

18. Demir, F.; Kalyoncu, I.H. Some nutritional, pomological, and physical properties of cornelian cherry (Cornus mas L.). J. Food Eng. 2003, 60, 335-341. [CrossRef]

19. Yousefi, B.; Abbasi, M.; Abbasi, M.M.; Jahanban-Esfahlan, R. Anti-proliferative properties of Cornus mas fruit in different human cancer cells. Asian Pac. J. Cancer Prev. 2015, 16, 5727-5731. [CrossRef]

20. Hosseinpour-Jaghdani, F.; Shomali, T.; Gholipour-Shahraki, S.; Rahimi-Madiseh, M.; Rafieian-Kopaei, M. Cornus mas: A review on traditional uses and pharmacological properties. J. Complement. Integr. Med. 2017, 11,63-69. [CrossRef]

21. Czerwinska, M.E.; Melzig, M.F. Cornus mas and Cornus officinalis- Analogies and differences of two medicinal plants traditionally used. Front. Pharmacol. 2018, 9, 894. [CrossRef]

22. Gholamrezayi, A.; Yaghubi, E.; Ghafouri, A. A review of probable effects of cornelian cherry. Fruit J. Biochem. Tech. 2019, 2, 71-74.

23. Milenković-Andjelković, A.; Andjelković, M.; Radovanović, A.; Radovanović, B.; Nikolić, V. Phenol composition, DPPH radical scavenging and antimicrobial activity of cornelian cherry (Cornus mas) fruit and leaf extracts. Hem. Ind. 2015, 69, 331-337. [CrossRef]

24. Moldovan, B.; Filip, A.; Clichici, S.; Suharoschi, R.; Bolfa, P.; David, L. Antioxidant activity of cornelian cherry (Cornus mas L.) fruits extract and the in vivo evaluation of its anti inflammatory effects. J. Funct. Foods 2016, 26, 77-87. [CrossRef]

25. Rop, O.; Mlcek, J.; Kramarova, D.; Jurikova, T. Selected cultivars of cornelian cherry (Cornus mas L.) as a new food source for human nutrition. Afr. J. Biotehnol. 2010, 9, 1205-1210.

26. Kazimierski, M.; Regula, J.; Molska, M. Cornelian cherry (Cornus mas L.)-characteristics, nutritional and pro-health properties. Acta Sci. Pol. Technol. Aliment. 2019, 18, 5-12.

27. Jaćimović, V.; Božović, Đ.; Jovančević, M. Selection of cornelian cherry (Cornus mas L.) in Upper Polimlje area. Agro Knowledge J. 2003, 4, 32-39.

28. Karadeniz, T. Promising cornelian cherries (Cornus mas L.) from the Northeastern Anatolia region of Turkey. J. Am. Pom. Soc. 2002, 56, 164-167.

29. AOAC. Official Methods of Analysis, 17th ed.; Association of Official Analytical Chemists: Washington, DC, USA, 2002.

30. Available online: https://CRAN.R--project.org/doc/FAQ/ (accessed on 22 June 2020).

31. IBM Corp. IBM SPSS Statistics for Windows; Armonk, SPSS Inc.: North Castle, NY, USA, 2019.

32. Bijelić, S.; Ninić-Todorović, J.; Jaćimović, G.; Gološin, B.; Cerović, S.; Vidicki, B. Morphometric characteristics of selected cornelian cherry genotypes. Contemp. Agric. 2007, 56, 130-137.

33. Bijelić, S.; Ninić-Todorović, J.; Gološin, B.; Cerović, S.; Ognjanov, V. Cornelian cherry (Cornus mas L.) selection at the Faculty of Agriculture in Novi Sad. In Proceedings of the 43th Croatian and 3th International Symposium on Agriculture, Opatija, Croatia, 18-21 February 2008; pp. 901-904.

34. Ninić-Todorović, J.; Cerović, S.; Gološin, B.; Bijelić, S.; Miletić, R. Pomological-biochemical characteristics of selected Cornelian cherry genotypes. Pomology 2005, 39, 395-399.

35. Yilmaz, K.U.; Ercisli, S.; Zengin, Y.; Sengul, M.; Kafkas, E.Y. Preliminary characterisation of cornelian cherry (Cornus mas L.) genotypes for their physico-chemical properties. Food Chem. 2009, 114, 408-412. [CrossRef]

36. Bijelić, S.; Gološin, B.; Ninić-Todorović, J.; Cerović, S.; Popović, B. Physicochemical fruit characteristics of cornelian cherry (Cornus mas L.) genotypes from Serbia. Hortscience 2011, 46, 849-853. [CrossRef]

37. Ercisli, S.; Yilmaz, S.O.; Gadze, J.; Džubur, A.; Hadžiabulić, S.; Aliman, J. Some fruit characteristics of cornelian cherries (Cornus mas L.). Not. Bot. Horti. Agrobot. 2011, 39, 255-259. [CrossRef]

38. Dokoupil, L.; Rezniček, V. Production end use of the cornelian cherry-Cornus mas L. Acta Univ. Agric. at Silvic. Mendel Bruno. 2012, LX, 49-58. [CrossRef] 
39. Jaćimović, V.; Božović, Đ. Chemical composition of cornelian cherry (Cornus mas L.) products and their relevance in human consumption. Contemp. Agric. 2007, 56, 150-157.

40. Božović, Đ.; Bosančić, B.; Velimirović, A.; Ercisli, S.; Jaćimović, V.; Keles, H. Biological characteristics of some plum cultivars grown in Montenegro. Acta Sci. Pol. Hortoru. 2017, 16, 35-45.

41. Tural, S.; Koca, I. Physico-chemical and antioxidant properties of cornelian cherry fruits (Cornus mas L.) grown in Turkey. Sci. Hortic. 2008, 116, 362-366. [CrossRef]

42. Sengul, M.; Eser, Z.; Ercisli, S. Chemical properties and antioxidant capacity of cornelian cherry genotypes grown in Coruh valley of Turkey. Acta Sci. Pol. Hortoru. 2014, 13, 73-82.

43. Maghradze, D.; Abashidze, E.; Bobokashvili, Z.; Tchipashvili, R.; Maghlakelidze, E. Cornelian cherry in Georgia. Acta Hortic. 2009, 818, 65-72. [CrossRef]

44. Ognjanov, V.; Cerović, S.; Ninić-Todorović, J.; Jaćimović, V.; Gološin, B.; Bijelić, S.; Vračević, B. Selection and utilization of table cornelian cherry (Cornus mas L.). Acta Hortic. 2009, 814, 121-124. [CrossRef]

45. Brindza, P.; Brindza, J.; Toth, D.; Klimenko, S.; Grigorieva, O. Slovakian cornelian cherry (Cornus mas L.) potential for cultivation. Acta Hortic. 2007, 760, 433-437. [CrossRef]

46. Drkenda, P.; Spahic, A.; Begić-Akagić, A.; Gaši, F.; Vranac, A.; Hudina, M.; Blanke, M. Pomological characteristics of some autochthonous genotypes of cornelian cherry (Cornus mas L.) in Bosnia and Herzegovina. Erwerbs-Obstbau 2014, 56, 59-66. [CrossRef]

47. Kucharska, A.; Sokol-Letowska, A.; Piorecki, N. Morphological, physical \& chemical, and antioxidant profiles of Polish varieties of cornelian cherry fruit (Cornus mas 1.). Food Sci. Technol. Qual. 2011, 3, 78-89.

48. Akagić, A.; Vranac-Oras, A.; Oručević-Žuljević, S.; Spaho, N.; Drkenda, P.; Bijedić, A.; Memić, S.; Hudina, M. Geographic variability of sugars and organic acids in selected wild fruit species. Foods 2020, 9, 462.

49. Klimenko, S. The cornelian cherry (Cornus mas L.) collection, preservation and utilization of genetic resources. J. Fruit Ornam. Plant Res. 2004, 12, 93-98.

50. Etienne, A.; Genard, M.; Lobit, P.; Mbeguie, A.; Mbeguie, D.; Bugaud, C. What controls fleshy fruit acidity? A review of malate and citrate accumulation in fruit cells. J. Exp. Bot. 2013, 64, 1451-1469. [CrossRef] [PubMed]

51. Milatović, D. Apricot; Scientific Pomological Society of Serbia: Čačak, Serbia, 2013.

52. Pantelidis, G.E.; Vasilakakis, M.; Manganaris, G.A.; Diamantidis, G. Antioxidant capacity, phenol, anthocyanin and ascorbic acid contents in raspberries, blackberries, red currants, gooseberries and cornelian cherries. Food Chem. 2007, 102, 777-783. [CrossRef]

53. De Pascual, T.B.; Sanchez, S. Anthocyanins, from plant to health. Phytochem. Rev. 2008, 7, 281-299. [CrossRef]

54. Ćujić, N.; Kundaković, K.; Šavikin, K. Anthocyanins-chemical analysis and biological activity. Lek. Sirov. 2013, 32, 19-37.

55. Dinda, B.; Kyriakopoulos, A.M.; Dinda, S.; Zoumpourlis, V.; Thomaidis, N.S.; Velegraki, A.; Markopoulos, C.; Dinda, M. Cornus mas L. (cornelian cherry), an important European and Asian traditional food and medicine: Etnomedicine, phytochemistry and pharmacology for its commercial utilization in drug industry. J. Ethopharmacol. 2016, 193, 670-690. [CrossRef]

56. Ochmian, I.; Oszmiański, J.; Lachowicz, S.; Krupa-Małkiewicz, M. Rootstock effect on physico-chemical properties and content of bioactive compounds of four cultivars cornelian cherry fruits. Sci. Hortic. 2019, 256, 108588. [CrossRef]

57. Ramos, S. Cancer chemoprevention and chemotherapy: Dietary polyphenols and signalling pathways. Mol. Nutr. Food Res. 2008, 52, 507-526. [CrossRef] [PubMed]

58. Mehta, R.G.; Murillo, G.; Naithani, R.; Peng, X. Cancer chemoprevention by natural products: How far have we come? Pharm. Res. 2010, 27, 950-961. [CrossRef] [PubMed]

59. Cosmulescu, S.; Trandafir, I.; Cornescu, F. Antioxidant capacity, total phenols, total flavonoids and color component of cornelian cherry (Cornus mas L.) wild genotypes. Not. Bot. Horti. Agrobo. 2019, 47, 390-394. [CrossRef]

60. Stanković, M.S.; Zia-Ul-Haq, M.; Bojović, B.M.; Topuzović, M.D. Total phenolics, flavonoid content and antioxidant power of leaf, flower and fruits from cornelian cherry (Cornus mas L.). Bulg. J. Agric. Sci. 2014, 20, 358-363.

61. Cetkovská, J.; Diviš, P.; Vespalcová, M.; Pořízka, J.; Řezníček, V. Basic nutritional properties of cornelian cherry (Cornus mas L.) cultivars grown in the Czech Republic. Acta Aliment. Hung. 2015, 44, 357-364. [CrossRef] 
62. Zlatković, B. The Technology of Processing and Storage of Fruit; Agricultural University: Belgrade, Serbia, 2003.

63. Kandic, R. Meteorological and Hydrological Yearbook 2013; IHMS, MNE: Podgorica, Montenegro, 2016. Available online: http://www.meteo.co.me/godisnjaci/GODISNJAK\%202013.pdf (accessed on 19 October 2020).

64. Kandic, R. Meteorological and Hydrological Yearbook 2014; IHMS, MNE: Podgorica, Montenegro, 2016. Available online: http://www.meteo.co.me/godisnjaci/GODISNJAK\%202014.pdf (accessed on 19 October 2020).

65. Kandic, R. Meteorological and Hydrological Yearbook 2015; IHMS, MNE: Podgorica, Montenegro, 2018. Available online: http://www.meteo.co.me/godisnjaci/GODISNJAK\%202015.pdf (accessed on 19 October 2020).

Publisher's Note: MDPI stays neutral with regard to jurisdictional claims in published maps and institutional affiliations.

(C) 2020 by the authors. Licensee MDPI, Basel, Switzerland. This article is an open access article distributed under the terms and conditions of the Creative Commons Attribution (CC BY) license (http://creativecommons.org/licenses/by/4.0/). 